УДК 343.8

DOI https://doi.org/10.51989/NUL.2021.6.26

\title{
ТЕОРЕТИЧНІ ПОГЛЯДИ НА ПРОБЛЕМИ ЗАПОБІГАННЯ ЮВЕНАЛЬНІЙ ЗЛОЧИННОСТІ В УКРАЇНI
}

\section{Сизоненко Антон Степанович,}

кандидат юридичних наук, доцент, заслужений юрист України, перший заступник директора

Департаменту персоналу Міністерства внутрішніх справ України

у статті автором розглянуто теоретичні погляди на проблеми запобігання ювенальній злочинності в Україні. Вказано, що кримінологічні та кримінально-правові заходи і засоби боротьби із кримінально протиправною активністю дітей мають застосовуватися лише у тісній взаємозалежності, оскільки тільки в такому випадку можна досягти бажаного результату у вигляді перевиховання девіантного підлітка. Автором указано на відсутність повноцінних наукових праць, які б вирішували проблему ювенальної віктимності; це може бути зумовлено тим, що психіка дитини є не до кінця сформованою, тому ї̈ досить складно повною мірою дослідити і прогнозувати ймовірну поведінку у тій чи іншій ситуації. Зазначено, що цінними $\epsilon$ роботи, присвячені ювенальній юстиції, оскільки остання в Україні тільки починає стрімко розвиватись, однак дещо не так, як у зарубіжних країнах. Наша держава здебільшого орієнтована на захист прав і свобод саме неповнолітніх кримінальних правопорушників, забуваючи про те, що сутність ювенальної юстиції полягає у захисті інтересів усіх дітей незалежно від ситуації, в якій вони опинились. Автор звертає увагу на те, що проблема участі громадськості у запобіганні злочинності неповнолітніх останнім часом усе частіше з'являється у працях науковців. Це можна пояснити прагненням знайти нові або надати друге життя забутим кримінально-правовим заходам та засобам. Висловлено скептичну позицію щодо дієвості інституту громадського вихователя, оскільки дуже рідко стороння особа, котра не має відповідної освіти, навичок і вмінь, здатна перевиховати девіантну дитину. Підсумовано, що злочинність неповнолітніх осіб нині є досить досліджуваним феноменом, що можна пояснити прагненням науковців позитивно вплинути на їі стабільно зростаючий показник. Однак донині залишається низка до кінця не вивчених таких питань: 1) детермінаційний комплекс ювенальної кримінально протиправної активності; 2) особа неповнолітнього кримінального правопорушника; 3) межі кримінальної відповідальності та покарання неповнолітніх осіб тощо.

Ключові слова: неповнолітній, злочинність, кримінальна активність, кримінальне правопорушення, кримінальне законодавство, кримінологія, віктимність, ювенальна юстиція.

\section{Syzonenko Anton. Theoretical views on the problems of juvenile delinquency prevention in Ukraine}

In the article the author considers theoretical views on the problems of juvenile delinquency prevention in Ukraine. It is pointed out that criminological and criminal-legal measures and means of combating criminally illegal activity of children should be used only in close interdependence, because only in this case the desired result can be achieved in the form of re-education of deviant adolescents. The author points out the lack of full-fledged scientific works that would solve the problem of juvenile victimhood, which may be due to the fact that the child's psyche is not fully formed, and therefore it is difficult to fully investigate and predict probable behavior in a given situation. It is noted that the works dedicated to juvenile justice are valuable, as the latter in Ukraine is just beginning to develop rapidly, but somewhat not as in foreign countries. Our state is mostly focused on protecting the rights and freedoms of juvenile offenders, forgetting that the essence of juvenile justice is to protect the interests of all children, regardless of the situation in which they find themselves. The author points out that the problem of public participation in the prevention of juvenile delinquency is increasingly appearing in the works of scientists. This can be explained by the desire to find new ones, or to give a second life to forgotten criminal law measures and means. There is a skeptical position on the effectiveness of the institution of public educator, as very rarely an outsider who does not have the appropriate education, skills and abilities is able to re-educate a deviant child. It is concluded that juvenile delinquency is currently a well-studied phenomenon, which can be explained by the desire of scientists to 
positively influence its steadily growing rate. However, to date there are a number of issues that have not been fully explored: 1) the determination of juvenile criminal activity; 2) the person of a juvenile criminal offender; 3) the limits of criminal liability and punishment of minors, etc.

Key words: juvenile, crime, criminal activity, criminal offense, criminal law, criminology, victimhood, juvenile justice.

Нині питання про запобігання ювенальній злочинності (злочинності неповнолітніх) привертають увагу багатьох науковців, залишаючись серед найскладніших і дискусійних. Ці питання досліджуються як науковцями-кримінологами, так і представниками інших галузей наукового знання. У новітній період розвитку вітчизняної кримінології (із початку $1990-x$ років по теперішній час) підготовлено значну кількість наукових праць, в яких висвітлено різні аспекти запобігання такій злочинності, зокрема обґрунтовано пропозиції щодо заходів, спрямованих на ії подолання. 3 огляду на це задля поглиблення та актуалізації наукових засад запобігання ювенальній злочинності на сучасному етапі потрібно проаналізувати і систематизувати попередні наукові напрацювання із цієї тематики, які становлять підґрунтя для іiї подальшого розроблення. Зважаючи на коло питань, які висвітлювалися у різних наукових працях щодо запобігання ювенальній злочинності (злочинності неповнолітніх), ці наукові праці можна умовно згрупувати за предметом дослідження, що дозволить певною мірою структурувати наявні кримінологічні знання стосовно запобігання такій злочинності.

Насамперед варто відзначити наукові праці, спеціально присвячені комплексному кримінологічному дослідженню злочинності неповнолітніх та основних питань запобігання цьому виду злочинності. Зокрема, серед таких наукових праць вирізняється ґрунтовністю докторська дисертація Н.С. Юзікової «Злочинність неповнолітніх: закономірності розвитку, теорія та практика запобігання і протидії їй в Україні» (2017р.). У цій дисертації наведено основні характеристики злочинності неповнолітніх як соціальної проблеми. У контексті закономірностей розвитку інститутів суспільства представлено кримінологічний аналіз особистості неповнолітнього, який вчиняє злочин. Запропоновано інституціонально-особистісний підхід до пізнання детермінації злочин- ності неповнолітніх. В окремому розділі роботи розглянуто такі питання, як міжнародні правила, принципи, рекомендації щодо гуманізації національного законодавства у сфері запобігання і протидії злочинності неповнолітніх; зарубіжний досвід програмного забезпечення запобігання і протидії злочинності неповнолітніх; гуманістичні засади і структура сучасної української державної політики запобігання злочинності неповнолітніх; заходи кримінально-правового характеру щодо неповнолітніх; концептуальні основи програмного забезпечення запобігання злочинності неповнолітніх. За результатами проведеного дослідження науковець запропонувала, зокрема, Типову програму запобігання злочинності неповнолітніх із закріпленням у такій програмі комплексу заходів, спрямованих на захист інтересів неповнолітніх, суспільства і держави від негативних посягань і дії криміногенних факторів, створення прийнятних умов для повноцінного розвитку та самореалізації молодого покоління [1, с. 324]. На нашу думку, саме зарубіжний та міжнародний досвід $\epsilon$ дуже важливим і цінним у справі боротьби зі злочинністю неповнолітніх осіб. Сучасні методи та заходи, наявні в українській юридичній практиці, вже давно $€$ рудиментарними і недієвими.

У теоретичній площині також заслуговує на увагу захищена у 2018 році дисертаційна робота М.В. Гричанюк «Механізм протидії злочинності неповнолітніх», у котрій представлено авторський погляд на концепцію такого механізму. У контексті зазначеного дослідження під цим механізмом запропоновано розуміти взаємодію елементів у межах конкретної системи заходів політичного, правового, організаційно-управлінського, ідеологічного, соціально-психологічного та іншого характеру, що $€$ сукупністю форм, методів і засобів, за допомогою яких органами кримінальної юстиції, спеціальними установами, органами і службами у справах дітей здійснюється різноманітна діяльність, 
спрямована на виявлення, усунення або нейтралізацію найширшого кола причин та умов, які сприяють вчиненню злочинів неповнолітніми, поновлення їхніх законних прав та інтересів, а також усунення наслідків злочинних діянь. До елементів механізму протидії злочинності віднесено цілі, завдання, суб'єкти, об'єкти, рівні, принципи, правове забезпечення цієї діяльності та напрями їі удосконалення. На основі такого підходу авторкою наведено пропозиції із удосконалення функціонування вищезазначеного механізму, зокрема щодо запровадження в Україні інститутів ювенальної юстиції і вдосконалення діяльності відповідних підрозділів Національної поліції України [2, с. 4, 10-14]. Кримінологічні та кримінальноправові заходи і засоби боротьби із кримінально протиправною активністю дітей мають застосовуватися тільки у тісній взаємозалежності, оскільки лише у такому випадку можна досягти бажаного результату у вигляді перевиховання девіантного підлітка. Саме тому запропонована науковцем праця, на нашу думку, $\epsilon$ досить цікавою і сучасною, а ідеї гідні для інтеграції у кримінальне законодавство.

Серед наукових праць, які стосуються базових питань про запобігання ювенальній злочинності (злочинності неповнолітніх), слід відзначити також дисертаційну роботу О.С. Моргуна «Злочинність неповнолітніх як об'єкт кримінологічного дослідження» (2013р.) та дисертаційну роботу Р.О. Бундза «Особлива жорстокість як ознака злочинності, що вчиняється неповнолітніми: детермінанти та попередження». У першій із названих праць узагальнено відмітні кримінологічні риси злочинності неповнолітніх та охарактеризовано особливості організаційно-профілактичної роботи з неповнолітніми особами, які вчиняють злочини [3]. Друга із названих праць охоплює вивчення злочинності неповнолітніх загалом і злочинів, учинених ними з особливою жорстокістю, а також детермінант формування особистості неповнолітніх, які вчиняють такі злочини, і напрямів запобігання їм на загальносоціальному, спеціально-кримінологічному та індивідуальному рівнях [4]. На жаль, як свідчить статистика, все частіше неповнолітні особи вчиняють тяжкі та особливо тяжкі кримінальні правопорушення, зокрема з особливою жорстокістю. Це свідчить про майже повну втрату кримінальним законодавством своєї дієвості у частині кримінальної відповідальності та покарання неповнолітніх осіб.

Для формування наукових засад запобігання ювенальній злочинності доволі значущою $\epsilon$ докторська дисертація С.Ф. Денисова «Злочинність кримінально активної частини молоді та ії запобігання в Україні». У зазначеній роботі автор оперує поняттями «злочинність кримінально активної частини молоді» та «молодіжна злочинність». Водночас поняття «кримінально активна частина молоді» слугує для позначення якісно-кількісної специфіки злочинів, учинених на території різних держав (міждержавних утворень і спільнот або територіальних складників держави: регіонів, областей, районів тощо) представниками певної підгрупи молоді - вікового контингенту 18-29 років. Під молодіжною злочинністю науковець розуміє сукупність злочинів, учинених за певний проміжок часу на певній території особами у віці 14-35 років, та сукупність учасників цих злочинів у тому ж самому віці [5, с. 11-12]. Оскільки в такому розумінні поняття «молодіжна злочинність» за обсягом містить ювенальну злочинність (злочинність неповнолітніх), обґрунтовані в цій роботі наукові положення щодо молодіжної злочинності та її запобігання варто враховувати у ракурсі спеціального дослідження механізму ювенальної злочинності. Поряд із названими вище науковими працями, що стосуються більшості базових питань запобігання ювенальній злочинності, наявна і велика кількість наукових праць, в яких досліджено окремі аспекти цієї тематики.

Зокрема, такими є дисертаційні роботи і монографії, присвячені формуванню кримінологічної характеристики і забезпеченню протидії (запобіганню) окремим видам (групам) злочинів, які вчиняються неповнолітніми особами. Серед цих досліджень варто назвати праці М.М. Корчового «Кримінологічні проблеми боротьби зі зґвалтуваннями, вчинюваними неповнолітніми» (2000р.) [6], Д.П. Смоленського «Групова корислива злочинність неповнолітніх: кримінологічне дослідження» 
(2011 р.) [7], I.В. Баклан «Кримінологічна характеристика та попередження злочинів у сфері обігу наркотичних засобів, психотропних речовин, їхніх аналогів або прекурсорів, що вчинюються неповнолітніми» (2007 р.) [8], В.В. Голіни «Кримінологічна характеристика злочинів проти життя та здоров'я особи, що вчиняються неповнолітніми» (2007р.) [9], Д.В. Петрова «Кримінологічна характеристика та запобігання грабежам і розбоям, що вчиняються неповнолітніми у громадських місцях» (2014р.) [10], К.О. Павлишин «Крадіжки, вчинені неповнолітніми: кримінологічний аналіз» (2019р.) [11]. У зазначеному контексті варто відзначити також дисертаційне дослідження Н.В. Яницької «Групова корисливо-насильницька злочинність молоді та ії попередження». У межах цього дослідження виділено дві вікові групи злочинців: $14-17$ і 18-28 років, що обумовлено особливостями їхнього фізичного і соціально-психологічного розвитку. Зважаючи на це, наведені в роботі положення і висновки у відповідній частині можуть ураховуватись і під час подальшого наукового опрацювання проблем ювенальної злочинності. Зокрема, це стосується кримінологічної характеристики групової корисливо-насильницької злочинності молоді, а також визначення загальносоціальних, спеціально-кримінологічних та віктимологічних заходів, спрямованих на попередження такої злочинності [12]. Що стосується віктимологічних досліджень у цій царині, потрібно відмітити, що, на жаль, нині в Україні майже відсутні такого плану роботи, пов'язані із неповнолітніми особами. На нашу думку, це може бути зумовлено тим, що психіка дитини $€$ не до кінця сформованою, тому її досить складно повною мірою дослідити і прогнозувати ймовірну поведінку в тій чи іншій ситуації.

Звертаючись до проблематики запобігання ювенальній злочинності (злочинності неповнолітніх), деякі автори акцентують увагу на регіональних (територіальних) особливостях. Зокрема, у цьому контексті слід відзначити монографію за загальною редакцією В.В. Голіни та В.Д. Ємельянова «Кримінологічні проблеми попередження злочинності неповнолітніх у великому місті: досвід конкретно-соціологічного дослідження» (2006р.) [13] та дисертацію Ю.А. Абросімової «Злочинність неповнолітніх та запобігання їй на регіональному рівні» (2009р.) [14]. Характеризуючи стан наукового розроблення проблеми запобігання ювенальній злочинності, не можна обійти увагою і низку наукових праць, присвячених дослідженню діяльності (ролі) окремих органів, установ, інституцій та інших суб'єктів стосовно запобігання цьому виду злочинності.

Більш детально питання про діяльність навчальних закладів щодо запобігання злочинності неповнолітніх розроблені у дисертації Л.С. Дубчак. У цій роботі представлено комплексний кримінологічний аналіз діяльності навчальних закладів різних типів і рівнів акредитації як суб'єктів запобігання злочинності неповнолітніх в Україні. Виявлено основні недоліки у діяльності загальноосвітніх, професійно-технічних та вищих навчальних закладів, які перешкоджають успішному запобіганню протиправної поведінки неповнолітніх. Запропоновано систему ранньої профілактичної роботи навчальних закладів із неповнолітніми і розроблено пропозиції щодо вдосконалення вітчизняного законодавства, яке регулює діяльність навчальних закладів за відповідним напрямом [15]. У ракурсі дослідження інституційного (суб'єктного) складника механізму запобігання ювенальній злочинності певний інтерес становлять окремі положення, викладені у дисертаційних роботах О.Г. Колба «Профілактика правопорушень серед неповнолітніх у слідчих ізоляторах МВС України» (1997р.) [16] та Ю.С. Завгородньої «Сучасні тенденції злочинності дітей та діяльність органів внутрішніх справ щодо їі запобігання» (2010р.) [17]. Проблема участі громадськості у запобіганні злочинності неповнолітніх все частіше останнім часом з'являється у працях науковців, що можна пояснити прагненням знайти нові або надати друге життя забутим кримінально-правовим заходам та засобам. Однак ми досить скептично відносимося до дієвості інституту громадського вихователя, оскільки дуже рідко стороння особа, яка не має відповідної освіти, навичок і вмінь, здатна перевиховати девіантну дитину.

Із урахуванням визнання на державному рівні необхідності реформування 
системи юстиції щодо неповнолітніх окремої уваги заслуговує дисертаційне дослідження І.М. Михайлової «Ювенальна юстиція в системі запобігання злочинам неповнолітніх» (2015р.). Оперуючи поняттям «ювенальна юстиція», авторка запропонувала його визначення як систему суспільних інститутів, діяльність яких спрямована на захист прав дитини, правовий і соціальний вплив на дитину та її оточення з використанням можливостей державних (судів, правоохоронних органів, служб у справах дітей, соціальних служб для дітей і молоді) структур і громадських організацій (адвокатури, дитячих фондів), а також волонтерських рухів із метою запобігання вчиненню ними протиправних діянь та соціальної реабілітації неповнолітніх правопорушників. Обґрунтовано авторське бачення щодо формування і розвитку системи ювенальної юстиції в Україні. Зокрема, за висновком дослідниці таку систему мають становити ювенальний суд як базовий орган у системі ювенальної юстиції; прокурори у справах неповнолітніх; адвокати у справах неповнолітніх; працівники кримінальної міліції у справах дітей МВС України; слідчі, які здійснюють провадження у справах неповнолітніх; соціальні працівники; служба пробації у складі кримінально-виконавчої інспекції Державної пенітенціарної служби України; органи та установи для дітей Державної пенітенціарної служби України; координатори та ведучі програм із відновного правосуддя; психологи і фахівцімедики, які працюють із неповнолітніми правопорушниками; вчителі, вихователі, соціальні педагоги, які працюють із дітьми та дітьми-правопорушниками [18]. Нині ювенальна юстиція в Україні тільки починає стрімко розвиватись, однак дещо не так, як у зарубіжних країнах. Наша держава здебільшого орієнтована на захист прав і свобод саме неповнолітніх кримінальних правопорушників, забуваючи про те, що сутність ювенальної юстиції полягає у захисті інтересів усіх дітей незалежно від ситуації, в якій вони опинились.

Серед наукових праць, присвячених дослідженню інституційного (суб'єктного) складника у запобіганні ювенальній злочинності, слід відзначити і дисертаційну роботу А.А. Коренюк «Взаємодія орга- нів пробації із релігійними організаціями у запобіганні рецидивним злочинам неповнолітніх в Україні» (2019р.). За результатами проведеного дослідження авторкою, зокрема, виокремлено різні форми взаємодії органів пробації із релігійними організаціями у запобіганні рецидивним злочинам неповнолітніх. Запропоновано шляхи вдосконалення практичної діяльності органів пробації та релігійних організацій у сфері боротьби із рецидивною злочинністю неповнолітніх, яке, за висновком авторки, має відбуватися на трьох рівнях: державному, громадському та особистісному [19]. Поряд із цим вирізняється оригінальністю наукова позиція Н.М. Градецької щодо віднесення до кола суб'єктів запобігання злочинності неповнолітніх такого соціального інституту, як сім'я. У дисертаційний роботі цієї дослідниці на основі аналізу поглядів вітчизняних правників на інститут сім'ї представлено його визначення та розкрито теоретичний аспект функцій, завдань і ролі сім'ї у життєдіяльності суспільства; основні напрями ії діяльності щодо запобігання злочинності, забезпечення нормального фізичного, морального, інтелектуального розвитку дитини як повноцінного члена суспільства. Водночас наголошено на особливому значенні виховної функції сім'ї, яка передбачає формування комплексу запобіжних заходів, що протистоять антигромадській поведінці неповнолітнього і вчиненню ним злочинів [20]. Родина є досить дієвим і серйозним способом перевиховання дитини, однак це має сенс лише у тому випадку, коли між членами такої родини наявні тісні позитивні взаємозв'язки, а батьки не мають деструктивних залежностей.

Про роль сім'ї у контексті проблеми злочинності неповнолітніх йдеться і в монографічному дослідженні Г.Д. Дідківської «Криміногенність сім'ї як фактор злочинності неповнолітніх». У цій монографії висвітлено особливості проблем сучасної сім'ї, причинний комплекс і криміногенний фактор сімейної сфери та механізм їх впливу на злочинність неповнолітніх, що дає змогу суб'єктам профілактики вже на ранніх стадіях деформації сімейних стосунків проводити заходи щодо попередження злочинності неповнолітніх [21]. Досліджуючи сукупність детермінант ювенальної 
злочинності (злочинності неповнолітніх), а також можливі заходи ії запобігання, науковці-кримінологи небезпідставно приділяють особливу увагу питанню щодо ролі засобів масової інформації у формуванні злочинної та правомірної поведінки неповнолітніх. Водночас усвідомлення важливості цих питань зумовило підготовку кількох дисертаційних робіт, спеціально присвячених такій тематиці. Першою серед них була дисертація О.I. Бугери «Проблеми використання засобів масової інформації для запобігання злочинів серед неповнолітніх» (2006 р.). У цьому дослідженні представлено кримінологічну оцінку недоліків діяльності засобів масової інформації, які сприяють злочинності серед неповнолітніх; підкреслено зв'язок між деструктивним впливом засобів масової інформації і протиправною поведінкою неповнолітніх; запропоновано заходи щодо загального соціального та спеціально-кримінологічного запобігання злочинів неповнолітніх шляхом удосконалення роботи засобів масової інформації [22]. Перший із зазначених науковців підтверджує нашу думку про те, що, говорячи про родину як про фактор, який може сприяти перевихованню, потрібно звертати увагу на мікроклімат і характеристику її членів.

Згодом зазначена тематика отримала подальший розвиток у дисертаційних роботах О.I. Напиральської «Вплив засобів масової комунікації на формування злочинної поведінки молоді» (2010р.) [23] та В.І. Галагана «Запобігання негативному впливу засобів масової інформації на формування злочинної поведінки неповнолітніх» (2015 р.) [24]. Серед інших значущих напрацювань представників кримінологічної науки, які прямо чи опосередковано стосуються питань про запобігання ювенальній злочинності, слід назвати дисертаційні роботи М.М. Биргеу «Попередження втягнення неповнолітніх у злочинну або антигромадську поведінку» (1996р.) [25], I.О. Топольскової «Кримінально-правові та кримінологічні аспекти боротьби із втягненням неповнолітніх у злочинну або іншу антигромадську діяльність» (2003р.) [26], С.М. Корецького «Кримінологічна характеристика девіантної поведінки неповнолітніх» (2003р.) [27], Д.Л. Виговського «Кримінальна субкультура в механізмі злочинності неповнолітніх» (2006 р.) [28], А.П. Гусака «Кримінологічні аспекти ресоціалізації неповнолітніх, засуджених за вчинення насильницьких злочинів, в умовах позбавлення волі» (2009р.) [29], Є.М. Вечерової «Некаральний кримінально-правовий вплив на неповнолітніх в Україні» (кримінологічні засади) (2010 р.) [30]. Зважаючи на те, що всебічне дослідження правових проблем потребує застосування компаративістського підходу, особливий інтерес становлять наукові праці, в яких аналізується досвід запобігання ювенальній злочинності у зарубіжних країнах. Серед таких наукових праць слід відзначити дисертації Т.С. Жукової «Соціальні засади запобігання злочинності молоді в Україні та в Італії (порівняльне дослідження)» (2011 р.) [31] та А.Ю. Дзюби «Запобігання злочинності неповнолітніх у ФРН» (2019 р.) [32]. Втягнення неповнолітніх осіб у кримінально-протиправну діяльність $€$ нині досить поширеним явищем, яке сприяє ії подальшій криміналізації. На жаль, не завжди дитина може повною мірою правильно оцінити ситуацію, в якій вона опинилася, та чим це для неї може закінчитися. У цьому контексті слід відмітити цінність правової освіти і виховної роботи у навчальних закладах.

Отже, проведене дослідження дозволило підсумувати, що злочинність неповнолітніх осіб нині $€$ досить досліджуваним феноменом, що можна пояснити прагненням науковців позитивно вплинути на її стабільно зростаючий показник. Однак донині існує низка до кінця не вивчених питань, а саме: 1) детермінаційний комплекс ювенальної кримінально протиправної активності; 2) особа неповнолітнього кримінального правопорушника; 3) межі кримінальної відповідальності та покарання неповнолітніх осіб. 


\section{ЛITEPATУРА:}

1. Юзікова Н.С. Злочинність неповнолітніх: закономірності розвитку, теорія та практики запобігання і протидії їй в Україні : дис. ... д-ра юрид. нау к: 12.00.08. Харків. нац. ун-т внутр. справ. Харків, 2017. 536 с.

2. Гричанюк М.В. Механізм протидії злочинності неповнолітніх : автореф. дис. ... канд. юрид. наук : 12.00.08. Харків. нац. ун-т внутр. справ. Харків, 2018. 18 с.

3. Моргун О.С. Злочинність неповнолітніх як об'єкт кримінологічного дослідження : автореф. дис. ... канд. юрид. наук : 12.00.08. Класич. приват. ун-т. Запоріжжя, 2013. 20 с.

4. Бундз Р.О. Особлива жорстокість, як ознака злочинів, що вчиняються неповнолітніми: детермінанти та попередження : автореф. дис. ... канд. юрид. наук : 12.00.08. Нац. ун-т «Львівська політехніка». Львів, 2019. 20 с.

5. Денисов С.Ф. Злочинність кримінально активної частини молоді та ії запобігання в Україні : автореф. дис. ... д-ра юрид. наук : 12.00.08. Класич. приват. ун-т. Запоріжжя, 2011. 36 c.

6. Корчовий М.М. Кримінологічні проблеми боротьби зі зґвалтуваннями, вчинюваними неповнолітніми : автореф. дис. ... канд. юрид. наук : 12.00.08. Нац. акад. внутр. справ України. Київ, 2000. 18 с.

7. Смоленський Д.П. Групова корислива злочинність неповнолітніх: кримінологічне дослідження : автореф. дис. ... канд. юрид. наук : 12.00.08. НАН України. Ін-т держави і права ім. В.М. Корецького. Київ, 2011. 16 с.

8. Баклан I.В. Кримінологічна характеристика та попередження злочинів у сфері обігу наркотичних засобів, психотропних речовин, їх аналогів або прекурсорів, що вчинюються неповнолітніми : автореф. дис. ... канд. юрид. наук : 12.00.08. НАН України. Ін-т держави і права ім. В.М. Корецького. Київ, 2007. 20 с.

9. Голіна В.В. Кримінологічна характеристика злочинів проти життя та здоров'я особи, що вчиняються неповнолітніми : монографія. Акад. прав. наук України, Iн-т вивчення проблем злочинності. Харків : Кроссроуд, 2007. 156 с.

10. Петров Д. В. Кримінологічна характеристика та запобігання грабежам і розбоям, що вчиняються неповнолітніми у громадських місцях : дис. ... канд. юрид. наук : 12.00.08. Київ : Національна академія прокуратури України, 2015. 255 с.

11. Павлишин К.О. Крадіжки, вчинені неповнолітніми: кримінологічний аналіз : монографія / наук. ред. В. В. Голіна. Нац. акад. прав. наук України, НДІ вивч. проблем злочинності ім. В. В. Сташиса. Харків : Право, 2019. 271 с.

12. Яницька Н.В. Групова корисливо-насильницька злочинність молоді та їі попередження : автореф. дис. ... канд. юрид. наук : 12.00.08. Нац. акад. внутр. справ України. Київ, 2000. 19 c.

13. Голіна В.В. Кримінологічні проблеми попередження злочинності неповнолітніх у великому місті: досвід конкретно-соціологічного дослідження : монографія. Акад. прав. наук України, Ін-т вивч. проблем злочинності. Харків : Право, 2006. 292 с.

14. Абросімова Ю.А. Злочинність неповнолітніх та запобігання їй на регіональному рівні. Автореф. дис...канд. юрид. наук: 12.00.08. Дніпропетровський держ. ун-т внутрішніх справ. Дніпро, 2009. 20 с.

15. Дубчак Л.С. Удосконалення діяльності навчальних закладів щодо запобігання злочинності неповнолітніх в Україні : автореф. дис. ... канд. юрид. наук : 12.00.08. Акад. адвокатури України. Київ, 2007. 20 с.

16. Колб О. Г. Профілактика правопорушень серед неповнолітніх у слідчих ізоляторах МВС України : дис. ...канд. юрид. наук : 12.00.08. Національна академія внутрішніх справ України. Київ, 1997. 239 с.

17. Завгородня Ю.С. Сучасні тенденції злочинності дітей та діяльність органів внутрішніх справ щодо її запобігання : автореф. дис. ... канд. юрид. наук : 12.00.08. Дніпропетр. держ. ун-т внутр. справ. Дніпро, 2010. 20 с.

18. Михайлова І.М. Ювенальна юстиція в системі запобігання злочинам неповнолітніх : автореф. дис. ... канд. юрид. наук: 12.00.08. Нац. акад. внутр. справ України. Київ, 2015. $20 \mathrm{c}$. 
19. Коренюк А.А. Взаємодія органів пробації з релігійними організаціями у запобіганні рецидивним злочинам неповнолітніх в Україні : автореф. дис. ... канд. юрид. наук : 12.00.08. Нац. акад. внутр. справ. Київ, 2019. 20 с.

20. Градецька Н.М. Сім'я як суб'єкт запобігання злочинності неповнолітніх : автореф. дис. ... канд. юрид. наук : 12.00.08. Класич. приват. ун-т. Запоріжжя, 2010. 20 с.

21. Дідківська Г.В. Криміногенність сім'ї як фактор злочинності неповнолітніх : монографія. Держ. фіскал. служба України, Нац. ун-т держ. податк. служби України. Київ : Центр учбової літератури, 2016. 202 с.

22. Бугера О.І. Проблеми використання засобів масової інформації для запобігання злочинів серед неповнолітніх : автореф. дис. ... канд. юрид. наук: 12.00.08. Акад. адвокатури України. Київ, 2006. 20 с.

23. Напиральська О.І. Вплив засобів масової комунікації на формування злочинної поведінки молоді : автореф. дис. ... канд. юрид. наук: 12.00.08. Класич. приват. ун-т. Запоріжжя, 2010. 20 с.

24. Галаган B.I. Запобігання негативному впливу засобів масової інформації на формування злочинної поведінки неповнолітніх : автореф. дис. ... канд. юрид. наук : 12.00.08. Нац. акад. внутр. справ. Київ, 2015. 20 с.

25. Быргэу М.М. Предупреждение вовлечения несовершеннолетних в преступное или антиобщественное поведение : дис... канд. юрид. наук : 12.00.08. Украинская академия внутренних дел. Киев, 1996. 185 с.

26. Топольскова І.О. Кримінально-правові та кримінологічні аспекти боротьби із втягненням неповнолітніх у злочинну або іншу антигромадську діяльність : дис. ... канд. юрид. наук : 12.00.08. Луганська академія внутрішніх справ ім. 10-річчя незалежності України. Луганськ, 2003. 198 с.

27. Корецький С.М. Кримінологічна характеристика девіантної поведінки неповнолітніх : дис. ... канд. юрид. наук: 12.00.08. Національна академія внутрішніх справ України. Київ, 2003. 189 c.

28. Виговський Д.Л. Кримінальна субкультура в механізмі злочинності неповнолітніх : дис. ... канд. юрид. наук. НАН України, Інститут держави і права ім. В.М. Корецького. Київ, 2006. 207 c.

29. Гусак А.П. Кримінологічні аспекти ресоціалізації неповнолітніх, засуджених за вчинення насильницьких злочинів, в умовах позбавлення волі : дис. ... канд. юрид. наук : 12.00.08. Волин. нац. ун-т ім. Лесі Українки. Луцьк, 2009. 275 с.

30. Вечерова Є.М. Некаральний кримінально-правовий вплив на неповнолітніх в Україні (кримінологічні засади) : автореф. дис. ... канд. юрид. наук : 12.00.08. Міжнар. гуманіт. ун-т. Одеса, 2010. 20 с.

31. Жукова Т.С. Соціальні засади запобігання злочинності молоді в Україні та Італії (порівняльне дослідження) : автореф. дис. ... канд. юрид. наук: 12.00.08. Класич. приват. ун-т. Запоріжжя, 2011. 20 с.

32. Дзюба А.Ю. Запобігання злочинності неповнолітніх у ФРН : дис. ... канд. юрид. наук : 12.00.08. Нац. акад. прав. наук України, НДІ вивч. проблем злочинності ім. В. В. Сташиса. Харків, 2019. 239 с. 